\title{
AGRICULTURE TRADE LIBERALIZATION AND POTENTIAL SECTORAL AND WELFARE GAINS FOR PAKISTAN
}

\author{
Muhammad Shahzad Iqbal,", Sofia Anwar ${ }^{2, *}$, Muhammad Aamir Khan ${ }^{3}$ and Azeem Sardar \\ ${ }^{1}$ School of Management Studies, The University of Faisalabad, Faisalabad, Pakistan \\ ${ }^{2}$ Department of Economics, Government College University, Faisalabad, Pakistan; \\ ${ }^{3}$ Department of Management Sciences, COMSATS Institute of Information Technology Islamabad, Pakistan. \\ "Corresponding author's e-mail: shahzad.iqbaal@gmail.com, dr.sofia.economist@gmail.com
}

\begin{abstract}
The study employed the latest developed MyGTAP model to calculate the effects of agricultural trade liberalization on the different sectors of the economy. In order to calculate the effects of agricultural trade liberalization on income distribution and economic growth, an analytical framework MyGTAP was developed where the standard GTAP model was linked with the latest available Social Accounting Matrix (SAM). The overall results show that the agriculture trade liberalization, modeled via a series of multilateral, bilateral as well as sectoral scenarios between Pakistan and the rest of the world, will cause a significant increase in economic growth. Despite some limitations, the Global CGE model developed in this study produces plausible results that would help to shed some light on the current debate about the trade liberalization effects on income inequality in Pakistan. The study used total three separate simulations. The results of the simulations suggest that manufacturing industries tend to increase the economic growth and to increase welfare across somewhat all household types.
\end{abstract}

Keywords: CGE, MyGTAP, household income, simulations, economic growth.

\section{INTRODUCTION}

The importance of trade has been recognized since long time ago by developed and developing countries for sustainable economic growth (Frankel and Romer, 1999; Irwin and Tervio, 2002; Wacziarg and Welch, 2008). Knowing the importance of trade, economies have adopted export oriented policies aiming to gain internal and external stability and efficient use of economic resource (Berg and Krueger, 2003). Trade liberalization has been recognized as the only mean to modernize and develop the industry, to achieve economy of scale and economic growth.

The trade liberalization in Pakistan started in 1988 by implementing the Structural Adjustment Program (SAP) of International Monitory Fund (IMF). SAP mainly focused on improving economic growth and balance of payments and reducing fiscal deficit and inflation (Shahbaz et al., 2008). The main objective of SAP was to develop an efficient and competitive industrial sector though import substitution (Akhtar and Ali, 2007) for improving employment, trade and growth. Various studies (Freund and Bolaky, 2008; Chang et al. 2009) have emphasized the importance of reforms not only in financial sector but labor market, legal sector and education sector also to complement the growth effects of trade policies. The success of SAP convinced Pakistan to join the World Trade Organization (WTO) in 1995. WTO and its associated programs convinced Pakistan to eliminate the import tariffs and subsidies gradually. The reduction and ultimately removal of trade barriers promotes the efficient use of economic resources and ultimately the economic growth.
Similarly, reduction in trade barriers resulting from different trade agreements helped Pakistan to explore new export opportunities in the South Asian Free Trade Agreement (SAFTA), China, European Union (EU) and India (Siddiqui et al., 2006).

The contribution of the agriculture sector to GDP was greater in early years of independence and under liberalization regime this sector also experienced an increase in trade and competiveness of cotton and basmati rice (Anwar et al., 2010) but no improvement in comparative advantage for wheat and sugarcane (Anwar et al., 2005). Despite of improvement in competitiveness; share of agriculture in GDP has reduced overtime. Now the trend has changed and the industrial, as well as services sectors, have significant shares in the overall GDP. If we take a look at current situation of Pakistan, we can observe a remarkable increase in the services sector GDP of Pakistan. In 2014-15, share of the agriculture sector to GDP was $25 \%$ whereas the share of the industrial sector to GDP was $19 \%$ and services sector's share to GDP was $56 \%$ (Pakistan Economic Survey, 2014-15).

Present study is an attempt to estimate the effects of trade reforms in agricultural sector on the various sectors of the economy measured by the changes in prices and income of people.

\section{MATERIALS AND METHODS}

The study is employing the Computable General Equilibrium (CGE) model in its global version and the main idea is drawn from Khan (2015). This section highlights the concept of 
CGE model. It further elaborate the Global Trade Analysis Project (GTAP) and MyGTAP.

Computable General Equilibrium Model (CGE): The study utilized CGE model to highlight the economy wide impact of different free trade agreements. CGE model is a useful tool to describe the complex relation of various sectors of the economy. It is helpful to interlink the diversified sectors of the economy through behavioral equations. It gives us numerical values which depict the effects of major policy reforms in the economy (Savard, 2003).

GTAP Model: The Global Trade Analysis Project (GTAP) model is the most widely known modeling system, a multisector, multi-region, computable general equilibrium model with perfect competition and returns to scale (McDougall et al., 1998). The centerpiece of the GTAP model is the internally consistent database with a base year provided by the individuals of the representative economies on inputoutput table.
The GTAP is a linear model built on the neoclassical theories and is comparative static in nature. This model is being employed for a number of applications (International trade, agricultural analysis, labor markets, etc). In order to perform the analysis at the country level, it uses the common global database. The model exhibits a utility maximizing and constant return to scale condition for all households and firms profit and considers that all markets are perfectly competitive. To solve the model, GEMPACK software is used (Harrison and Pearson, 1996). In reality, the GTAP model is a multiregion CGE model aimed to deal with trade policy reforms with the help of comparative static analysis as explained by Adams et al. (1998).

MyGTAP Model: The MyGTAP model; newly developed by Minor and Walmsley (2012) is employed in this study. The data about multiple households and labor types have been taken from the latest SAM (2007-08) of Pakistan.

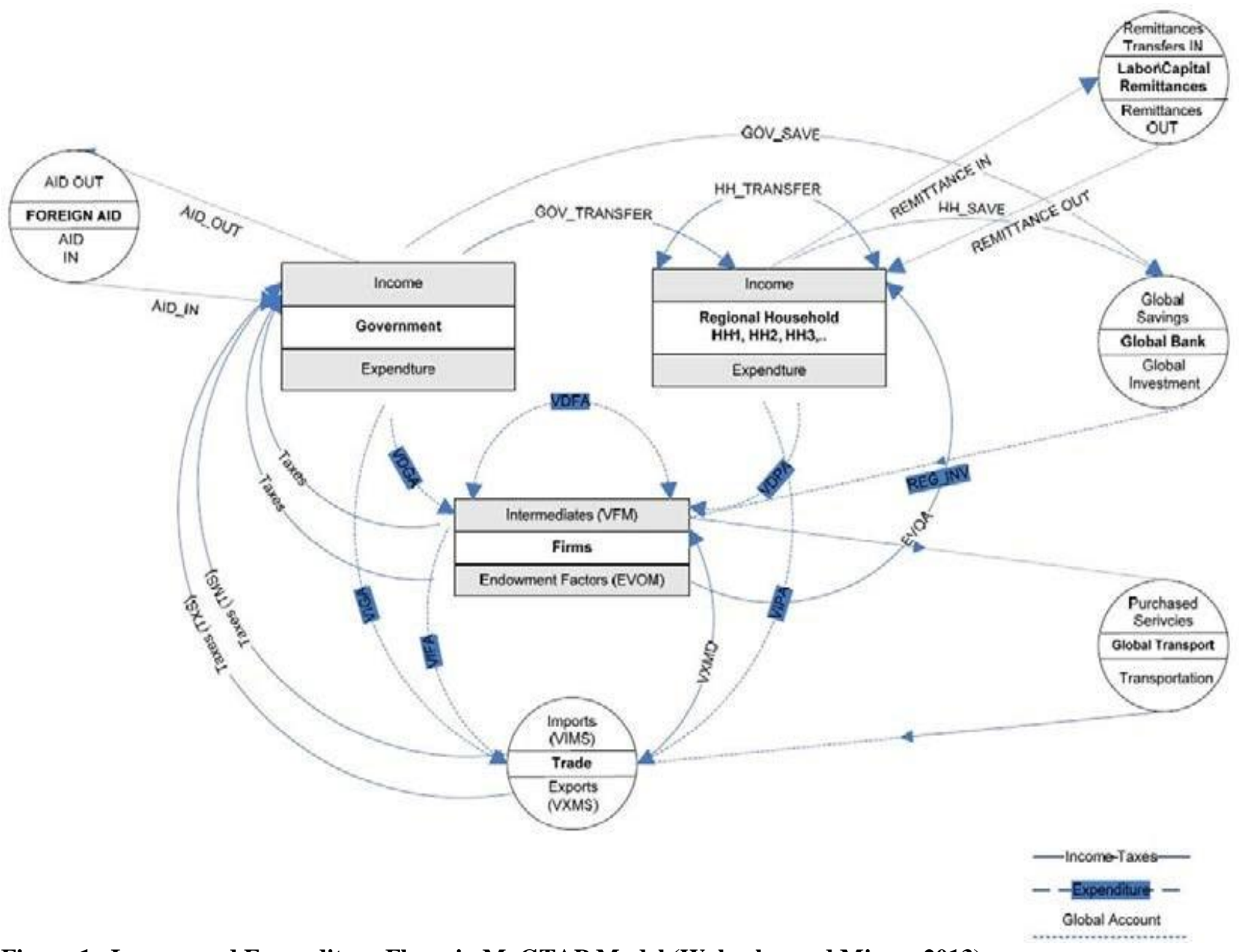

Figure 1. Income and Expenditure Flows in MyGTAP Model (Walmsley and Minor, 2013). 
MYGTAP is actually the extension of GTAP developed by Hertel (1997). The purpose of this extension is to incorporate regional household specification plus different inter regional transfers. MyGTAP, unlike the standard GTAP contains more options that help in the context of multiregional. The model is explained in figure 1.

\section{RESULTS AND DISCUSSION}

The Commutable General Equilibrium model used in this study has been fully calibrated and then various policy experiments have been performed by varying the related parameters.

Simulations used in the study: The simulations used in the study are presented in table 1 .

\section{Table 1. The simulation schemes of the study.}

S1 50 percent reduction in import taxes and export subsidies in all regions and all tradable commodities (Multilateral)

S2 100 percent reduction in all import taxes and export subsidies in all regions and all tradable commodities (Multilateral)

S3 Multilateral trade liberalization of agriculture (no import tax or subsidy in all agriculture tradable commodities)

\section{Simulation Results:}

GDP and production: Figure 2 illustrates the impacts of all simulation on the real GDP of Pakistan. The change in GDP is shown from the base year (2007-08) value. The results of GDP of different trade liberalization scenarios is modest, ranging from positive 0.41 percent with 50 percent removal of import tariff and export subsidies to -0.01 percent for Pakistan in the case of liberalized agricultural trade. The gain is maximum $(0.81 \%)$ in case of complete removal of tariffs and subsidies on all imports and exports.

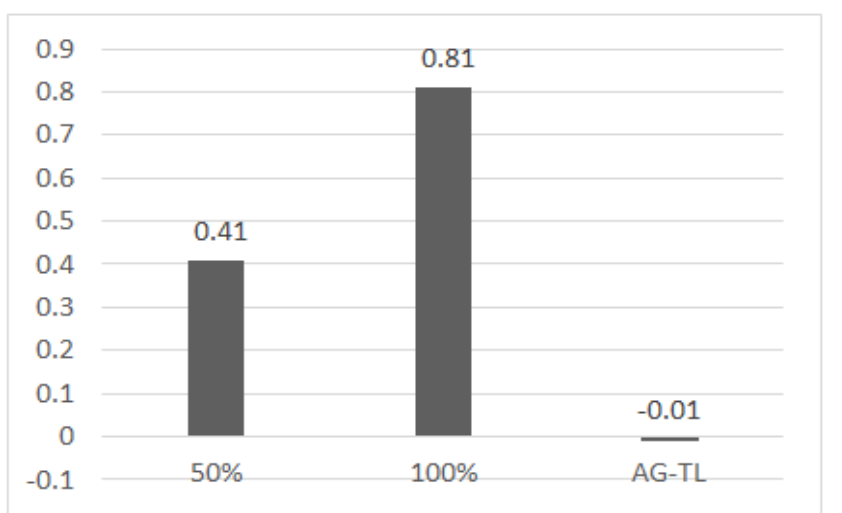

Figure 2. Percent changes in real GDP.
Exports and imports: A shift in domestic price level and imports can be seen upon removal of tariffs which ultimately triggered substitution between imports and domestically produced goods (Mankiw, 2007). The reduction or removal of import tariff and export subsidy helps to increase the imports of an economy due to lower price level as well as increase in exports due to increased competitiveness owing to decreased domestic prices. The removal of tariffs also helps the economy to increase its output because of exports and easily availability of inputs at competitive price level. However, the local production for domestic sales decreases due to the substitution effect (Acharyya, 2011).

The effects of tariff elimination differ significantly across sectors, stimulating reallocation of outputs due to substantial difference in the sectoral arrangement of imports and exports, initial tariff rates, and the trade elasticity's. Table 2 illustrates the simulated changes in Pakistan's imports and exports resulting from the three simulations.

In the case of the half and full trade liberalization simulations, the results show that overall imports and exports change almost equally resulting in no notable change in the trade balance. On the imports side, the most notable changes during simulation 1, i.e. removal of import tariff and export subsidies by 50 Percent worldwide is for Pakistan's import of oil (33.7 percent from base line), vegetable oils (7.3 percent from base line), sugar (14.5 percent from base line), textile (10.90 percent from base line), wearing apparel (11.80 percent from base line), chemical rubber and plastic (7.35 percent from base line), Auto parts (6.53 percent from base line), electrical items (8.41 percent from base line), mineral products nec (3.4 percent from Base line), Machinery and equipment nec (4.79 percent from base line), utilities (3.85 percent from base line) and transport sector (5.83 percent from base line), Manufacturers nec ( 5 percent from base line), this is due, in large part to tariff changes and imports from worldwide. Most agricultural products experience increase in imports during simulation 3 i.e. agricultural trade liberalization and the increase is from zero to 3.14 percent.

Sectoral prices: The immediate effects of trade liberalization are on the prices of goods. The study expects a decrease in price of imports in case of all three simulations that ultimately may reduce the prices of domestically produced goods because of interconnection that exist in the domestic economy. Most domestic prices are prone to fall, that will lead to a switch to export production. Meanwhile, there is a possibility of a switchover to imported commodities. The income of different institutions in the model is expected to change due to the offset effect that will change the production structure of an economy. Those export-oriented sectors then have a positive impact on factors of production used intensively in their production. Similarly, a reduction in production is expected in the commodities that are being substituted by imports. 
Iqbal, Anwar, Khan \& Sardar

Table 2. Changes in Pakistan's imports and exports constant 2007 prices (Percent and Millions US\$).

\begin{tabular}{|c|c|c|c|c|c|c|c|c|}
\hline & \multicolumn{4}{|c|}{ Imports } & \multicolumn{4}{|c|}{ Exports } \\
\hline & $\begin{array}{c}\text { BAU } \\
(\text { million \$) }\end{array}$ & $\begin{array}{c}50 \% \\
\text { TL }\end{array}$ & $\begin{array}{c}100 \% \\
\text { TL }\end{array}$ & $\begin{array}{c}\text { AGR- } \\
\text { TL }\end{array}$ & $\begin{array}{c}\text { BAU } \\
(\text { million \$) }\end{array}$ & $\begin{array}{c}50 \% \\
\text { TL }\end{array}$ & $\begin{array}{c}100 \% \\
\text { TL }\end{array}$ & $\begin{array}{c}\text { AGR- } \\
\text { TL }\end{array}$ \\
\hline Paddy rice & 90.12 & 1.23 & 2.47 & 0.79 & 75.77 & -7.09 & -16.22 & 5.73 \\
\hline Wheat & 171.68 & 3.19 & 0.52 & 1.71 & 137.31 & 7.08 & 16.03 & 9.37 \\
\hline Cereal grains nec & 2.82 & -3.90 & -6.74 & -0.71 & 2.58 & -3.10 & -5.04 & 1.16 \\
\hline Vegetables, fruit, nuts & 296.05 & 2.31 & 4.77 & 2.82 & 215.47 & 3.01 & 6.30 & 12.86 \\
\hline Oil seeds & 7.93 & 3.30 & 6.6 & 3.10 & 20.63 & 71.51 & 142.36 & 40.20 \\
\hline Sugar cane, sugar beet & 64.33 & -5.43 & -12.28 & 0.58 & 54.50 & -1.28 & -4.20 & 8.95 \\
\hline Plant-based fibers & 48.83 & 3.22 & 6.57 & 0.25 & 45.81 & -3.06 & -6.22 & 0.37 \\
\hline Cattle, sheep, goats, horses & 1.43 & -4.90 & -7.69 & 0.70 & 1.39 & -4.32 & -6.47 & 2.16 \\
\hline Livestock and Meat Products & 39.60 & -4.77 & -8.08 & 0.53 & 36.51 & -3.56 & -5.64 & 3.12 \\
\hline Forestry & 6.47 & 9.12 & 19.78 & 2.32 & 5.36 & 11.94 & 27.05 & 8.21 \\
\hline Fishing & 38.71 & -2.61 & -4.21 & -0.31 & 32.96 & -1.24 & -1.21 & 2.25 \\
\hline Minerals & 136.61 & 0.78 & 1.98 & 0.07 & 106.24 & 1.28 & 2.98 & 0.06 \\
\hline Oil & 0.55 & 33.73 & 68.18 & 0.00 & 0.52 & 12.69 & 24.77 & 0.00 \\
\hline Processed Food & 1825.23 & 5.62 & 11.20 & 0.26 & 1421.44 & 7.73 & 15.50 & 0.24 \\
\hline Vegetable oils and fats & 139.84 & 7.33 & 14.16 & 0.26 & 121.88 & -47.12 & -64.78 & 0.25 \\
\hline Dairy products & 35.85 & -12.69 & -25.02 & 0.31 & 29.63 & -9.08 & -18.06 & 0.30 \\
\hline Sugar & 42.92 & 14.50 & 29.26 & 0.37 & 30.39 & 4.15 & 9.0 & 0.36 \\
\hline $\begin{array}{l}\text { Beverages and tobacco } \\
\text { products }\end{array}$ & 198.9 & 8.74 & 20.38 & 0.07 & 141.04 & 9.65 & 18.37 & 0.06 \\
\hline Textiles & 9664.46 & 10.90 & 23.70 & 0.62 & 8367.7 & 12.44 & 24.34 & 0.61 \\
\hline Wearing apparel & 3023.97 & 11.80 & 26.25 & 0.56 & 2613.35 & 16.98 & 33.99 & 0.56 \\
\hline Leather products & 514.35 & -5.05 & -8.49 & 0.83 & 468.46 & -2.64 & -3.71 & 0.82 \\
\hline Wood products & 54.12 & 3.82 & 9.26 & 0.41 & 45.26 & 6.78 & 15.71 & 0.40 \\
\hline Petroleum, coal products & 689.53 & 2.43 & 4.94 & 0.06 & 623.81 & 8.11 & 17.70 & 0.06 \\
\hline $\begin{array}{l}\text { Chemical, rubber, plastic } \\
\text { products }\end{array}$ & 426.52 & 7.35 & 16.87 & 0.29 & 374.53 & 10.01 & 22.76 & 0.29 \\
\hline Mineral products nec & 452.14 & 3.14 & 6.85 & 0.21 & 306.69 & -0.46 & -0.39 & 0.20 \\
\hline Metals and products & 656.26 & 1.49 & 2.99 & 0.38 & 619.85 & 1.83 & 5.62 & 0.38 \\
\hline Motor vehicles and parts & 68.84 & -6.53 & -13.91 & -0.23 & 63.04 & 6.24 & 12.35 & 0.22 \\
\hline Electronic equipment & 29.00 & 8.41 & 21.07 & 0.55 & 28.06 & 2.09 & 6.88 & 0.57 \\
\hline Machinery and equipment nec & 392.60 & 4.79 & 9.48 & 0.39 & 370.78 & 13.32 & 26.67 & 0.39 \\
\hline Manufactures nec & 527.40 & 5.00 & 10.72 & 0.47 & 472.90 & 10.78 & 20.27 & 0.46 \\
\hline other utilities & 0.52 & 3.85 & 9.62 & 0.00 & 0.52 & 3.85 & 9.62 & 0.00 \\
\hline Construction & 66.98 & 1.88 & 4.76 & 0.21 & 66.98 & 1.88 & 4.76 & 0.21 \\
\hline Trade & 51.44 & -0.43 & 0.19 & 0.27 & 51.44 & -0.43 & 0.19 & 0.27 \\
\hline Transport equipment nec & 1157.89 & 5.38 & 12.45 & 0.17 & 1157.89 & 5.38 & 12.45 & 0.17 \\
\hline Communication & 126.11 & -0.83 & -0.75 & 0.26 & 126.11 & -0.83 & -0.75 & 0.26 \\
\hline All Services & 2483.34 & -0.56 & -0.28 & 0.28 & 2483.34 & -0.56 & -0.28 & 0.28 \\
\hline
\end{tabular}

The simulations results for some key industries (Table 3) show a reduction in price level (as expected) of all traded commodities under all scenarios following the different trade liberalization simulations used in this study. Construction prices will converge into positive values for all scenarios but the increase is very marginal. The maximum reduction in prices was seen if Pakistan completely liberalizes trade with rest of the world. The notable reduction was witnessed in Petroleum, coal products $(-11.15 \%)$, oil (-9.63\%), auto parts sector by $(-9.5 \%)$ and transport sector by $(-5.71 \%)$. 
Table 3. Sectoral prices in Pakistan (percent changes from base line).

\begin{tabular}{lccc}
\hline Products & 50\% TL & 100\% TL & AGR- TL \\
\hline Minerals & 2.22 & 4.43 & -0.05 \\
Oil & -4.81 & -9.63 & -0.01 \\
Vegetable oils and fats & -1.62 & -3.24 & -0.16 \\
Wearing apparel & -1.30 & -2.61 & -0.10 \\
Wood products & -1.48 & -2.95 & -0.10 \\
$\begin{array}{l}\text { Petroleum, coal } \\
\text { products }\end{array}$ & -5.57 & -11.10 & -0.02 \\
$\begin{array}{l}\text { Chemical, rubber and } \\
\text { plastic products }\end{array}$ & -2.47 & -4.93 & -0.07 \\
Metals and Products & -1.93 & -3.86 & -0.07 \\
Motor vehicles and parts & -4.75 & -9.50 & -0.05 \\
$\begin{array}{l}\text { Electronic equipment } \\
\text { Machinery and }\end{array}$ & -1.54 & -3.08 & -0.08 \\
equipment nec & -2.53 & -5.06 & -0.06 \\
Manufactures nec & & & \\
other utilities & -1.51 & -3.02 & -0.08 \\
Transport equipments & -1.96 & -3.91 & -0.08 \\
\hline
\end{tabular}

The positive influence on Pakistan exports during simulation 1 and simulation 2 can be seen on the textile $(12.44 \%$ in S1 and $24.34 \%$ in S2), wearing apparels $(16.98 \%$ in S1 and $33.99 \%$ in S2), chemical, rubber and plastic nec (10\%\% in S1 and 22.76 in S2), machinery and equipment nec (13.32\% in S1and $26.07 \%$ in S2), processed food $(7.73 \%$ in S1 and $15.50 \%$ in S2). The most notable increase has been seen in oil seed sectors as the exports will rises up to 80.36 percent from base line during $\mathrm{S} 2$. While the prominent deterioration has been seen in leather $(-3.71 \%)$. Paddy rice $(-16.32 \%)$, milk ($18.06 \%)$.

Terms-of-trade impact: The terms-of-trade (TOT), is the ratio of prices that a country receives for its exports to the prices of imports that a country pays (Chang et al., 2009). The changes in the value of TOT reflect the overall welfare of an economy due to change in price level. This study uses different reciprocal liberalization involved in Free Trade Agreement (FTA) and usually this result in two counterbalancing effects; i) liberalization of Pakistan's imports would reduce production costs in Pakistan thus increasing the supply of its exports to global markets. This may be expected to lower prices received for exports for each unit and ii) after an FTA partners cut their prices on Pakistani exports, their demands for Pakistani exports will rise, and subsequently it will increase Pakistani export prices. The net effect will be reliant on whichever of these two effects is higher.

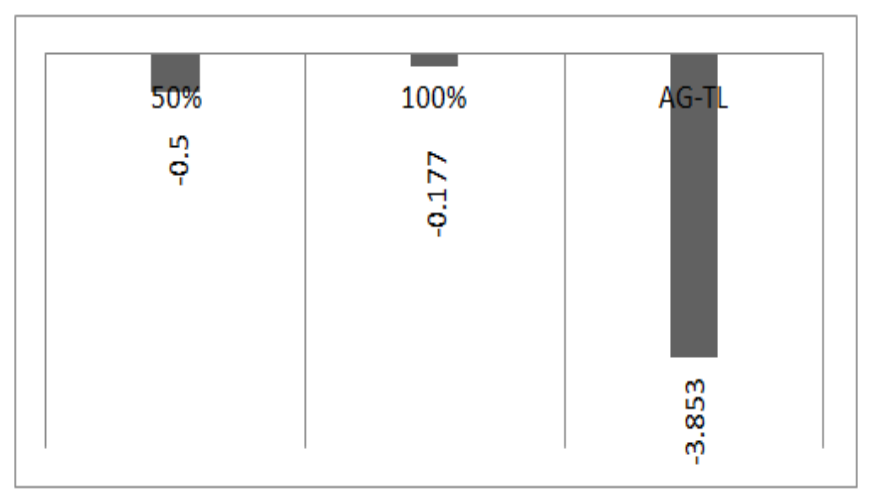

Figure 3. Changes in Pakistan terms of trade (TOT) (percentage).

Figure 3 demonstrates the effects of different simulation on the Pakistan's terms-of trade. It implies that terms-of-trade of Pakistan deteriorate in most of the cases due to changes in prices. However, with European Union Pakistan's terms of trade will appreciate as after the GSP plus status now almost 90 percent of Pakistan exports to Europe will be duty free.

Pakistan's terms-of-trade appreciate by 0.35 percent from base line because of changes in its prices for its exports to EU with respect to prices of imports it pays for the EU. The highest deterioration is seen with FTA with China (-2.66 percent) and when Pakistani liberalizes its industrial sector worldwide the terms of trade decreases by 3.85 percent.

Changes in household income: The uniqueness of MYGTAP model lies in its feature which disaggregates the representative household of the standard household into

Table 4. Percent changes in Pakistan real household income.

\begin{tabular}{lccclccc}
\hline Categories & Sim-I & Sim-II & Sim-III & Categories & Sim-I & Sim-II & Sim-III \\
\hline Large and medium farm Sindh & 1.67 & 3.34 & -1.97 & Landless agri. Lab Sindh & 0.08 & 0.16 & 0.86 \\
Large and medium farm Punjab & 1.50 & 3.03 & -2.30 & Landless agri. Lab Punjab & 0.37 & 0.74 & 0.93 \\
Large and medium farm other & 1.73 & 3.46 & -1.57 & Landless agri. Lab other Pakistan & 0.04 & 0.08 & 0.56 \\
Small farm Sindh & 0.15 & 0.37 & -1.23 & Rural non-farm quintile & 0.49 & 1.01 & 0.50 \\
Small farm Punjab & 0.07 & 0.17 & -0.23 & Rural non form quintile 2 & 0.62 & 1.24 & 0.53 \\
Small farm other Pakistan & 0.27 & 0.55 & -1.33 & Rural non-farm quintile other & 1.88 & 3.96 & 0.52 \\
Landless farmers Sindh & 0.03 & 0.07 & -0.77 & Urban quintile 1 & 1.40 & 3.53 & 0.64 \\
Landless farmers Punjab & 0.11 & 0.26 & -0.21 & Urban quintile 2 & 1.77 & 3.58 & 0.61 \\
Landless farmers other Pakistan & 0.96 & 1.99 & 0.76 & Urban other & 1.47 & 3.02 & 0.72 \\
\hline
\end{tabular}


regional household. We disaggregated the households into 18 categories for detailed analysis. The data was acquired from the latest available SAM (2007-08) for Pakistan.

The disaggregated analysis used in the study is different from the traditional "national welfare analysis" analysis of CGE studies. In MyGTAP, different types of household are affected in different way due to any policy change, so the poor household should be given more attention while designing the trade policy. Any change in wage leads to change in per capita income (Minor and Walmsley, 2012).

The results are of mix nature where some household are beneficiary while others are worst off in terms of income. The major beneficiaries are large and medium sized household. In case of land income, the income of all household that own land increased (H-LF, H-MF, H-SF). Although small rural farmers of KPK and Sindh province witnessed decreases in their income by $(-0.96 \%)$ and $(-1.99$ percent $)$ during simulation (S1) and (S2). The household of rural non-farm showed a decrease in income with minimal value. In all urban household types the effects are unbiased to all households. All household obtain a positive increase in their capital income. Overall, factor income remains positive for almost all households. If there is no import tariff and export subsidy between Pakistan and India, then income of every household type will increase but that increase is merely modest. Note withstanding with the reduction in import tariff but also the unit costs of imports if they are sourced from India would be lower than the imports unit costs if they are sourced from other countries. Thus, it will reduce Pakistan import prices from India because now the potential of Pakistani imports from India will be improved due to the cheaper prices.

Conclusion: We attempted to investigate the impact of agricultural trade liberalization at household and aggregate level. The newly developed MyGTAP Model that utilized the latest available SAM (2007-08) for Pakistan.

The results show that agricultural trade liberalization, in all scenarios will cause a significant increase in economic growth. The results of simulation - "squeezing government expenditure" suggest that manufacturing industries tend to increase the economic growth and to increase welfare across somewhat majority of household types. Agricultural trade liberalization widens inequality and thus promotes relative poverty. The liberalization policy therefore is not suggested to work as panacea to reduce the inequality rather to ensure the sustainable economic growth and welfare of Households through derived factor on manufacturing.

\section{REFERENCES}

Acharyya, R. 2011. A note on quantitative trade restrictions, income effects and wage inequality. Eco. Mod. 28:26282633.
Adams, P.D., M. Horridge, B.R. Parmenter, and X.G. Zhang. 1998. Long-run Effects on China of APEC Trade Liberalization. Monash University. The Centre of Policy Studies (COPS), Melbourne, Australia.

Akhter, N. and A. Ali. 2007. Does Trade Liberalization Increase the Labor Demand Elasticities? Evidence from Pakistan. MPRA Paper, University Library of Munich, Germany.

Anwar, S., Z. Hussain and M.S. Javed. 2005. Comparative advantage and competitiveness of wheat crop in Pakistan. Lah. J. Econ. 10:101-110

Anwar, S., F. Shaukat and Z. Hussain. 2010. Impact of trade liberalization on export of cotton from Pakistan: a time series analysis. Sarhad J. Agric. 26:297-304.

Berg, A. and A. Krueger. 2003. Trade, Growth, and Poverty: A Selective Survey. IMF Working Paper 03/30. International Monetary Fund, Washington, D.C., USA.

Chang, R., L. Kaltanic and N.V. Loayza. 2009. Openness can be good for growth: The role of policy complementarities. J. Dev. Eco. 90:33-49.

Frankel, J.A. and D. Romer. 1999. Does trade cause growth?. A. Eco. Rev. 89:379-399.

Freund, C. and B. Bolaky. 2008. Trade, regulations and income. J. Dev. Eco. 87:309-321.

Anonymous. 2014-15. Pakistan Economic Survey 2014-15. Finance and Economic Affairs Division, Ministry of Finance, Govt. of Pakistan, Islamabad, Pakistan.

Hertel, T.W. and M.E. Tsigas. 1997. Structure of GTAP. Center for Global Trade Analysis. Purdue University, Global Economic Analysis, Indiana, USA.

Irwin, D.A. and M.Tervio. 2002. Does trade raise income? Evidence from the twentieth century. J. Int. Eco. 58:1-18.

Khan, M.A., A.Saboor and A.Q. Mohsin. 2015. Impact of agricultural trade liberalization on Income inequality in Pakistan. J. Agric. Res. 28:28-37.

Mankiw, N.G. 2007. Macroeconomics, $7^{\text {th }}$ Ed. Worth Publishers, New York.

McDougall, R., A. Elbehri and T.P. Truo. 1998. Global Trade, Assistance, and Protection: The GTAP 4 Data Base. Center for Global Trade Analysis, Purdue University, Indiana, USA.

Minor, P. and T. Walmsley. 2012. MyGTAP Data Program: A program for customizing and edtending the GTAP Database- Multiple households, split factors, remittances, foreign aid transfers. Presented at the $15^{\text {th }}$ Annual Conference on Global Economic Analysis; June 27-29, 2012, Geneva, Switzerland.

Savarad, L. 2003. Poverty and Income Distribution in a CGEHousehold Micro-Simulation Model: Top-Down/Bottom Up Approach. Available online with updates at http://EconPapers.repec.org/RePEc:lvl:lacicr:0343. 
Shahbaz, M., K. Ahmad and A.R. Chaudhary. 2008. Economic growth and its determinants in Pakistan. The Pak. Dev. Rev. 47:471-486.

Siddiqui, R., A.R. Kemal, R. Siddiqui, V. Robichand and M.A. Kemal. 2006. Tariff reduction, fiscal adjustment and poverty in Pakistan: A CGE-based analysis. MIMAP Project- Phase II. Islamabad, Pakistan.

Wacziarg, R. and K.H. Welch. 2008. Trade liberalization and growth: New evidence. The WB Eco. Rev. 22:187-231. 